BARBARA GórA

Uniwersytet im. Adama Mickiewicza w Poznaniu

Biblioteka Uniwersytecka

\title{
"Poznańczycy": Edward Kuntze, Stefan VrTel-WierczyńSKI, AleKSANDER BirKenMajer I ICH REFORMATORSKA POLITYKA BIBLIOTECZNA
}

W 1918 roku, po 123 latach niewoli, odradzała się państwowość polska, a każda dziedzina życia, gospodarki, nauki i kultury powoli ulegała przeobrażeniom.

\section{Biblioteki polskie w przededniu powstania II RP}

Tuż przed powstaniem II RP biblioteki naukowe i publiczne w Polsce znajdowały się w trudnym położeniu. Działo się tak z dwóch powodów. Wśród przyczyn zewnętrznych należy wymienić ,izolacjonizm” międzynarodowy, wynikający - de facto - z nieistnienia Polski. Do przyczyn wewnętrznych zaliczymy warunki panujące na ziemiach polskich - antypolską politykę zaborców i podległość trzem prawodawcom: Austrii (najbardziej liberalnej), Rosji i Niemcom. Inaczej przedstawiała się sytuacja w krajach wolnych, gdzie państwa wspomagały istnienie bibliotek. Tam widoczne były zmiany w metodach i formach pracy. Powstawały szkoły bibliotekarskie i związki zawodowe bibliotekarzy, wydawano czasopisma fachowe. W zachodniej Europie rozpoczęły swoją działalność pierwsze biblioteki specjalne, mające na celu dokumentację piśmiennictwa fachowego - w ten sposób tworzono 
zręby bibliotekarstwa specjalnego i informacji naukowej. Bibliotekarstwo powszechne, jako dziedzina działalności praktycznej, rozwijało się w Stanach Zjednoczonych, zajmując właściwe miejsce w systemie oświaty i życiu kulturalnym społeczeństwa amerykańskiego: „(...) zastosowano wolny dostęp do półek i nieskomplikowany układ zbiorów, wydłużono godziny udostępniania, wypracowano łatwy w użyciu katalog (krzyżowy), wyodrębniono działy do obsługi dzieci, młodzieży, ludzi w jakiś sposób upośledzonych, emigrantów"1.

W Polsce głównie inteligencja, przeniknięta duchem społecznikowskim i demokratycznym, powoływała do życia - w duchu obywatelskiej powinności - towarzystwa oświatowe i kulturalne. Tak powstały Warszawskie Towarzystwo Dobroczynności czy Polska Macierz Szkolna. W ich strukturach rozpoczęły działalność lokalną niewielkie biblioteki. Sytuacja zmieniła się po 1905 roku, gdy w Królestwie Polskim zelżał ucisk policyjny. W Warszawie powstały wówczas Towarzystwo Czytelń m. Warszawy oraz Towarzystwo Biblioteki Publicznej wraz z biblioteką (1907), założoną i prowadzoną według najlepszych wzorów zagranicznych. W innych większych miastach również podjęto podobne inicjatywy².

Natomiast w środowiskach uniwersyteckich (Kraków, Lwów, Warszawa) szczególnego znaczenia nabrało opracowanie bibliografii narodowego piśmiennictwa i wydawanie źródeł do historii Polski. Powstawały wielkie dzieła bibliograficzne, do których należą Historia literatury Feliksa Bentkowskiego czy Bibliografia polska Karola Estreichera ${ }^{3}$.

\section{Biblioteki w II Rzeczypospolitej}

Tymczasem granice Polski nie były jednoznacznie określone, stąd odrodzone państwo skierowało cały swój wysiłek na rzecz ich ostatecznego utrwalenia. Trwały działania wojenne na wschodzie Polski i przygotowania do plebiscytów na Śląsku, Warmii i Mazurach. „Ten brak oczekiwanego zainteresowania państwa sprawami bibliotek naukowych i oświatowych (...) spowodował, że właściwym koordynatorem różnych poczynań bibliotekarskich i głównym autorem akcji, które zmierzały do wypracowania zasad jednolitego systemu bibliotecznego, stał się w okresie międzywojennym

\footnotetext{
1 Z. Gaca-Dąbrowska, Bibliotekarstwo II Rzeczypospolitej. Zarys problemów organizacyjnych i badawczych, Warszawa 2007, s. 21.

2 Tamże, s. 18.

3 Tamże, s. 22.
} 
Związek Bibliotekarzy Polskich”4. To właśnie dzięki poczynaniom Związku Bibliotekarzy Polskich i nieprzeciętnym osobom, które w nim działały, wypracowano nowe zasady organizacji bibliotekarstwa w II Rzeczypospolitej. Jednak brak ustawy o bibliotekach, która prawnie organizowałaby całość bibliotekarstwa w Polsce, nie sprzyjał jego rozwojowi. Nie udało się uchwalić ustawy o bibliotekach głównie z powodów finansowych - sprzeciwiały się związki samorządowe $e^{5}$. Jeśli chodzi o tę zasadniczą ustawę, niestety Polska była niechlubnym wyjątkiem w Europie ${ }^{6}$. Paradoksalnie jednak to okres dwudziestolecia był najbardziej znaczącym okresem w historii bibliotekarstwa polskiego. Wśród twórców nowego bibliotekarstwa należy wymienić: Aleksandra Birkenmajera, Józefa Grycza, Edwarda Kuntzego, Adama Łysakowskiego, Jana Muszkowskiego, Stefana Vrtela-Wierczyńskiego, Helenę Radlińską i Mariana Łodyńskiego. Działając w tym okresie, stali się oni synonimem przemian w środowisku bibliotekarskim i tworzenia nowej polityki bibliotecznej.

Z bogatej działalności Edwarda Kuntzego (1880-1950), Stefana Vrtela-Wierczyńskiego (1886-1963) i Aleksandra Birkenmajera (1890-1967) w niniejszym artykule zostaną omówione te momenty, które dotyczą okresu ich dyrektorowania w Bibliotece Uniwersyteckiej w Poznaniu oraz wkładu, jaki wnieśli w rozwój bibliotekarstwa i kultury polskiej.

\section{EDWARD KUNTZE (1880-1950)}

\section{Biblioteka Uniwersytecka w Poznaniu (1919-1926)}

Kiedy dr Edward Kuntze przemierzał latem 1919 roku drogę z Krakowa do Poznania, wydawało się, że ciągle jeszcze z oddali dochodzą odgłosy walk powstańców wielkopolskich (16 lutego 1919 roku - rozejm w Trewirze powstanie zostało formalnie zakończone, ale walki w Wielkopolsce trwały do 1920 roku) ${ }^{7}$. W czerwcu 1919 roku ważyły się także losy granic Polski

\footnotetext{
4 Tamże, s. 52.

5 Tamże, s. 51.

6 „Po I wojnie światowej ustawę taką wprowadziła u siebie Czechosłowacja (1919), potem Bułgaria i Dania (1920), następnie Belgia (1921), Estonia (1924), Finlandia (1927) oraz Litwa (1935). Również w Związku Radzieckim Dekret Komisarzy Ludowych z 1920 r., stworzył podstawy prawne dla zorganizowania jednolitej sieci bibliotek w kraju”. Zob. tamże, s. 51.

${ }^{7}$ „W styczniu 1920 r. jednostki powstańcze wojsk wielkopolskich uroczyście inkorporowały miasta i tereny Poznańskiego przyznane Polsce traktatem wersalskim”. Zob. M. Olszewski, Powstanie Wielkopolskie 1918-1919, Poznań 1978, s. 14-15.
} 
w Wersalu. Traktat Wersalski miał duże znaczenie dla Polski, ponieważ na mocy jego uchwał ostatecznie ustalono zachodnią granicę Polski, a sukces Powstania Wielkopolskiego przyczynił się do usankcjonowania takiej decyzji ${ }^{8}$.

Nie sposób wyobrazić sobie, jak przebiegałaby nasza granica, w Poznańskiem i na Pomorzu, i jak ułożyłyby się losy Górnego Śląska, gdyby zwycięski przebieg powstania wielkopolskiego nie zaimponował mocarstwom zachodnim i nie zachęcił Ślązaków do trzykrotnej próby wyzwolenia się spod jarzma pruskiego'.

Odradzająca się Polska potrzebowała ludzi mądrych i odpowiedzialnych ${ }^{10}$. Jednym z nich był dr Edward Kuntze, pracownik Biblioteki Jagiellońskiej. Sam Fryderyk Papée ${ }^{11}$ (dyrektor Biblioteki od 1905 roku) nakłonił go do rezygnacji z pracy nauczyciela w gimnazjum. E. Kuntze dał się poznać w nowym środowisku jako świetny organizator i piewca nowoczesnych metod pracy bibliotekarskiej (wspierając w tym ówczesnego dyrektora Biblioteki Jagiellońskiej). Zmiany dotyczyły wprowadzenia numerus currens, założenia inwentarza i katalogu systematycznego ${ }^{12}$. Rok po odzyskaniu przez Polskę niepodległości, E. Kuntze został powołany na dyrektora Biblioteki Uniwersytetu Poznańskiego. Wybór spotkał się z aprobatą środowiska bibliotekarskiego, bo nowy dyrektor z całą pewnością należał do filarów nowoczesnego bibliotekarstwa.

Oficjalne przejęcie Biblioteki Cesarza Wilhelma przez władze polskie odbyło się 30 czerwca 1919 roku. Kaiser-Wilhelm-Bibliothek powstała w 1902 roku $^{13}$. Jej celem było krzewienie kultury niemieckiej wśród Niemców

${ }^{8}$ Dzieje Polski, pod red. J. Topolskiego, Warszawa 1977, s. 629, 647.

9 B. Hulewicz, Wielkie wczoraj w małym kregu, Warszawa 1968, s. 167.

${ }^{10}$ „Kraj połączony z trzech zaborów potrzebował jak najszybciej ludzi na różne stanowiska, także w dziedzinie nauki. Kraków i Lwów dostarczał uczonych, profesorów i bibliotekarzy do nowo otwartych uniwersytetów w Warszawie, Wilnie i Poznaniu”. Zob.: H. Lipska, Dyrektor Biblioteki Jagiellońskiej Edward Kuntze, Kraków 1965, s. 40.

11 „Karierę bibliotekarską rozpoczął Edward Kuntze w Bibliotece Jagiellońskiej, za dyrekcji znakomitego historyka Fryderyka Papée, w roku 1906, jako pomocnik bibliotekarza, czyli tzw. amanuenta". Zob.: Twórcy nowoczesnego bibliotekarstwa polskiego, pod red. B. Kocowskiego, Wrocław 1974, s. 166.

12 „Wśród osób przyjętych do pracy w latach 1908-1918 najwybitniejszymi i najlepszymi pracownikami byli Edward Kuntze i Marian Łodyński (od 1908)”. Zob.: J. Baumgart, Edward Kuntze jako bibliotekarz, „Biuletyn Biblioteki Jagiellońskiej” 1971, nr 1, s. 6.

13 „Głównym celem biblioteki miała być germanizacja Księstwa Poznańskiego, przy czym miał współdziałać cały naród niemiecki. Skutek odezwy po całych Niemczech był nadzwyczajny. 
i podbudowanie ich morale. W Poznaniu pod panowaniem pruskim takie budowle nie były wyjątkiem ${ }^{14}$. Gmach prezentował się okazale, stał przy ulicy Rycerskiej, jednej z głównych ulic miasta (dziś Franciszka Ratajczaka - pierwszego powstańca wielkopolskiego, który poległ 27 grudnia, pierwszego dnia powstania). Przejęta biblioteka była nowoczesną instytucją, wyposażoną $\mathrm{w}$ odpowiednie urządzenia techniczne, takie jak: dźwig, transportery, pocztę pneumatyczną. Wartość zastanych zbiorów bibliotecznych nie była naukowa, tym niemniej pozostawiono je i rozpoczęto gromadzenie poloników, by książnica mogła spełniać zadanie polskiej biblioteki uniwersyteckiej ${ }^{15}$. Dary przekazywały głównie instytucje i osoby prywatne (m.in. Polska Akademia Umiejętności, Towarzystwo Naukowe Warszawskie, Jan Motty - księgozbiór prawniczy, Antoni Jurasz - publikacje z dziedziny laryngologii. Poza tym kupowano książki i czasopisma oraz prowadzono wymianę. Do stworzenia polskiej biblioteki uniwersyteckiej na niedawnych ziemiach zaboru pruskiego włączyły się m.in. rządy Belgii, Czechosłowacji i Francji. Drugą ważną sprawą była właściwa organizacja pracy w bibliotece. Edwardowi Kuntzemu pomogła praktyka w Bibliotece Jagiellońskiej. Dlatego też decyzje podejmowane przy organizowaniu biblioteki okazywały się niezwykle trafne. Chodziło na przykład o wykorzystanie instrukcji pruskiej do opracowania zbiorów aż do czasu powstania instrukcji polskiej ${ }^{16}$ czy o pozostawienie niemieckiego katalogu (z biegiem czasu z naniesionymi uwagami polskimi). Zreorganizowano jedynie katalog systematyczny, likwidując systematyczny układ książek w magazynie na rzecz numerus currens. Zorganizowano czytelnie, wypożyczalnie, zmieniono charakter księgozbioru podręcznego - z publicznego na naukowy, by mógł służyć nowo powstałemu Uniwersytetowi Poznańskiemu ${ }^{17}$.

Około 300 nakładców ofiarowało swoje wydawnictwa, prawie wszystkie większe biblioteki swoje dublety, a wiele osób prywatnych swoje księgozbiory”. Zob. Biblioteka Uniwersytecka w Poznaniu, „Przegląd Biblioteczny” 1927, nr 1, s. 152-153.

14 Przykładem takich budowli był zamek, zbudowany w latach 1905-1910, siedziba, która miała raz na zawsze potwierdzić przynależność Wielkopolski do Rzeszy. Zob.: Z. Pałat, Pruska „Twierdza na Wschodzie” [w:] Zamek cesarski w Poznaniu, Poznań 2003, s. 55.

15 „Biblioteka ces. Wilhelma miała bowiem charakter nie ściśle naukowy, lecz oświatowy. Celem jej była popularyzacja wiedzy wśród szerokich warstw społeczeństwa, przy tendencji germanizacyjnej". Zob.: S. Vrtel-Wierczyński, Biblioteka Uniwersytecka w Poznaniu 1919-1929, Poznań 1929 , s. 7.

${ }^{16}$ Instrukcja polska powstała w 1934 roku. Autorem był Józef Grycz.

17 „W Kronice Uniwersytetu Poznańskiego napisano: «Szybki rozwój Biblioteki Uniwersyteckiej, to bezsporna zasługa dyrektora dra Kuntzego i licznych jego współpracowników»”. Zob.: J. Baumgart, Bibliotekarstwo, biblioteki, bibliotekarze. Wybór prac, Warszawa 1983, s. 219. 
Kolejnym krokiem dyrektora było zorganizowanie kursów zawodowych. Pomysł przeprowadzenia kursów dla pracowników biblioteki w celu podniesienia ich kwalifikacji bądź uzyskania awansu zawodowego należy traktować jako rzecz całkowicie autorską. Pierwszy przygotowano dla bibliotekarzy ze średnim wykształceniem. Już 1 listopada 1919 roku rozpoczęto szkolenia, które trwały do lipca następnego roku i kończyły się egzaminem przed Państwową Komisją Egzaminacyjną. Wiosną 1920 roku miał się odbyć kurs z programem dla bibliotekarzy naukowych (z wykształceniem wyższym), zatwierdzony przez Ministerstwo Wyznań Religijnych i Oświecenia Publicznego. Tymczasem z powodu wojny polsko-sowieckiej wszystko zmieniło swój bieg. Dopiero po podpisaniu traktatu w Rydze w 1921 roku można było powrócić do normalnego trybu życia. Zainicjowany w styczniu 1921 roku kurs dla bibliotekarzy naukowych trwał tylko do maja, bo dyrektor Kuntze został powołany w trybie pilnym w szeregi Delegacji Mieszanej Polsko-Sowieckiej Komisji Specjalnej w Moskwie, której przewodniczył od 1923 roku. Powołanie to dokumentuje telegram zachowany w Archiwum Biblioteki Uniwersyteckiej, wysłany w imieniu Rządu przez Ministra Macieja Rataja.

\section{Il. 1. Telegram od ministra Macieja Rataja, maj 1921}

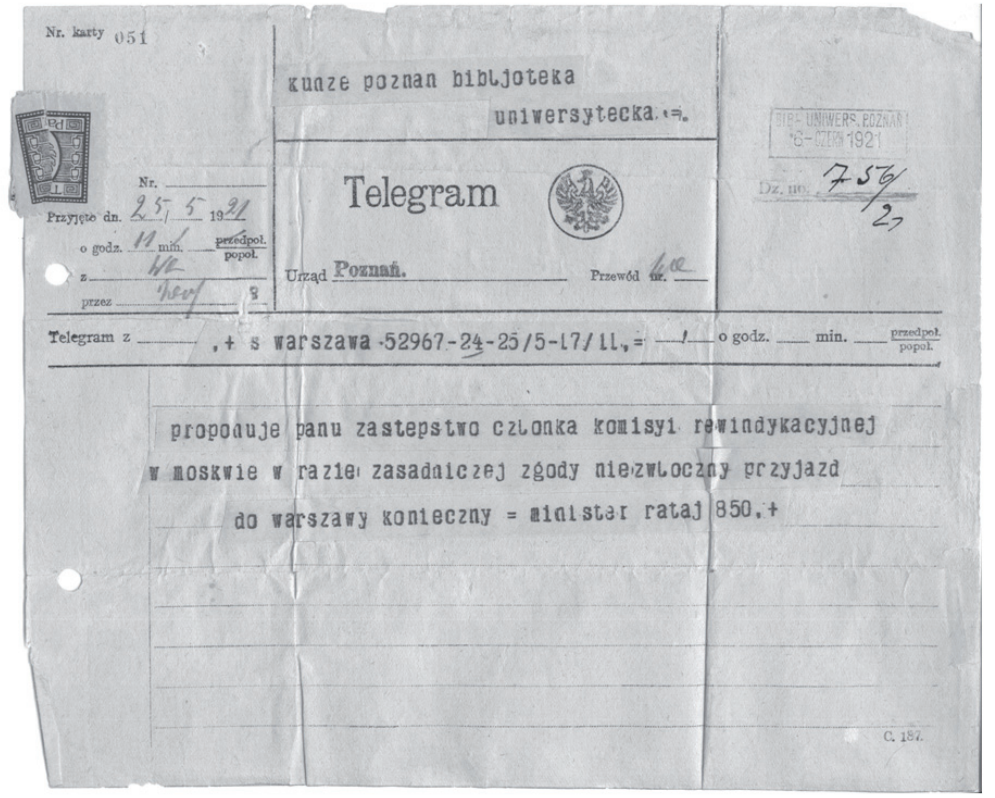

Źródło: Archiwum Biblioteki Uniwersyteckiej w Poznaniu, sygn. 145. 
Il. 2. Pismo do Senatu Uniwersytetu Poznańskiego informujące o wyjeździe Dyrektora do Moskwy, czerwiec 1921.

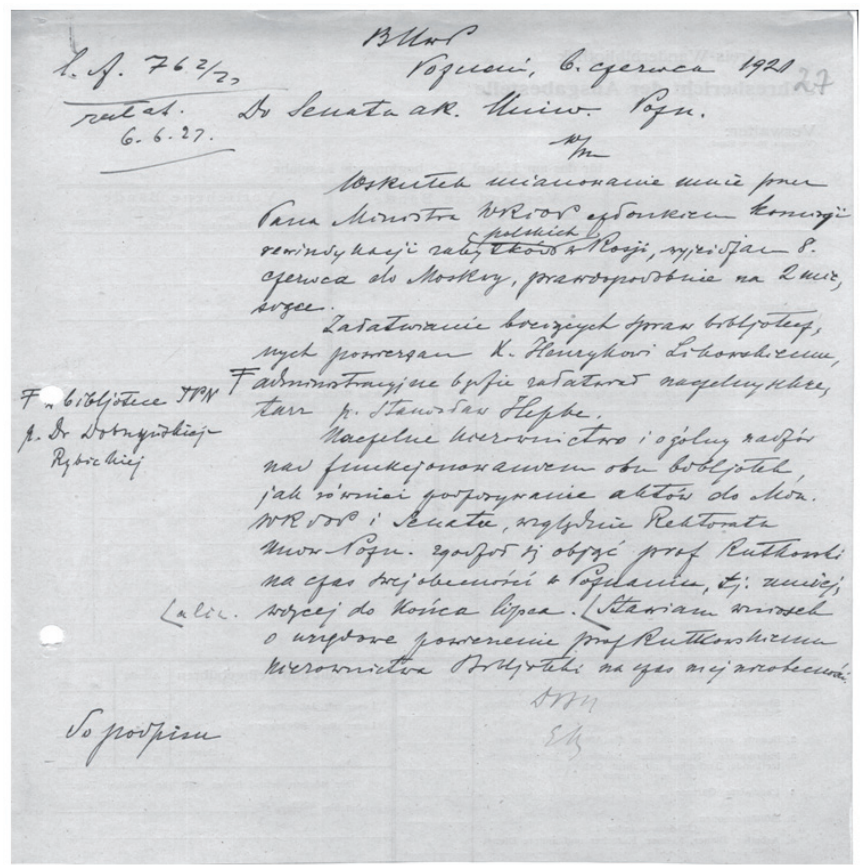

\section{Il. 3. Koncept do Rektoratu Uniwersytetu Poznańskiego, styczeń 1922.}

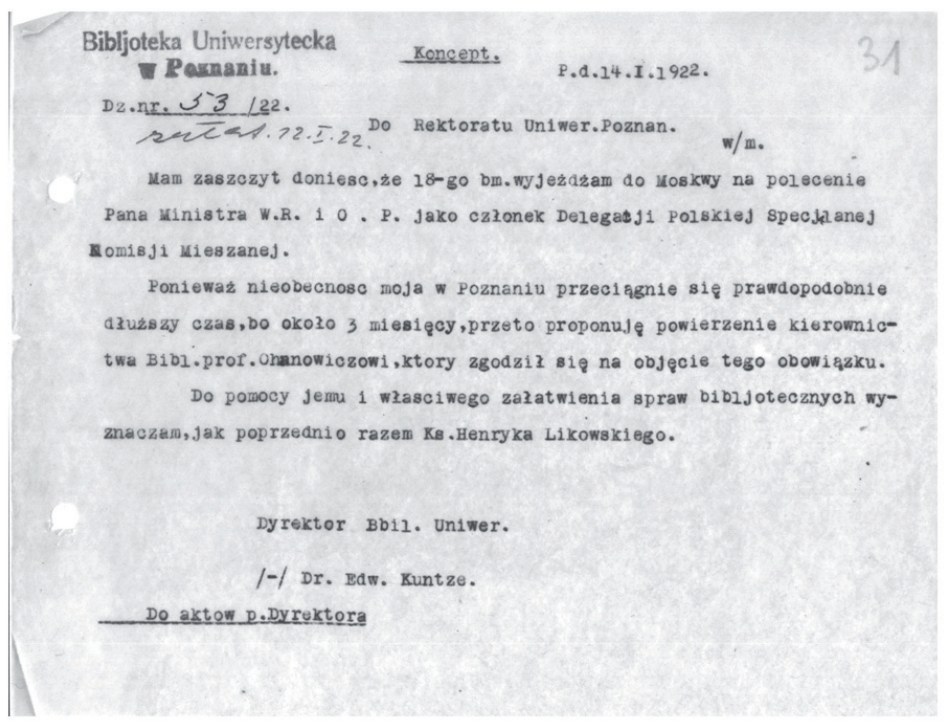

Źródło: Archiwum Biblioteki Uniwersyteckiej w Poznaniu, sygn. 145. 


\section{Wyjazd do Moskwy}

Pobyt dyrektora w Moskwie miał trwać trzy miesiące. Ostatecznie dr Kuntze przebywał tam z przerwami przez pięć lat (od 1921 do 1926 roku), wielokrotnie wracając do biblioteki w Poznaniu.

W tym okresie Dyrektor otrzymał urlop bezpłatny „z ważnych względów publicznych", natomiast zastępstwo powierzył ks. Henrykowi Likowskie$\mathrm{mu}^{18}$. Za poniesiony trud i pracę w Komisji Specjalnej E. Kuntze zasłużył na wdzięczność i uznanie nie tylko bibliotekarzy, ale i świata kultury.

\section{Il. 4. Ministerstwo Spraw Zagranicznych do Prezesa Polskiej Delegacji w Komisji Mieszanej i Reewakuacyjnej, styczeń 1925.}

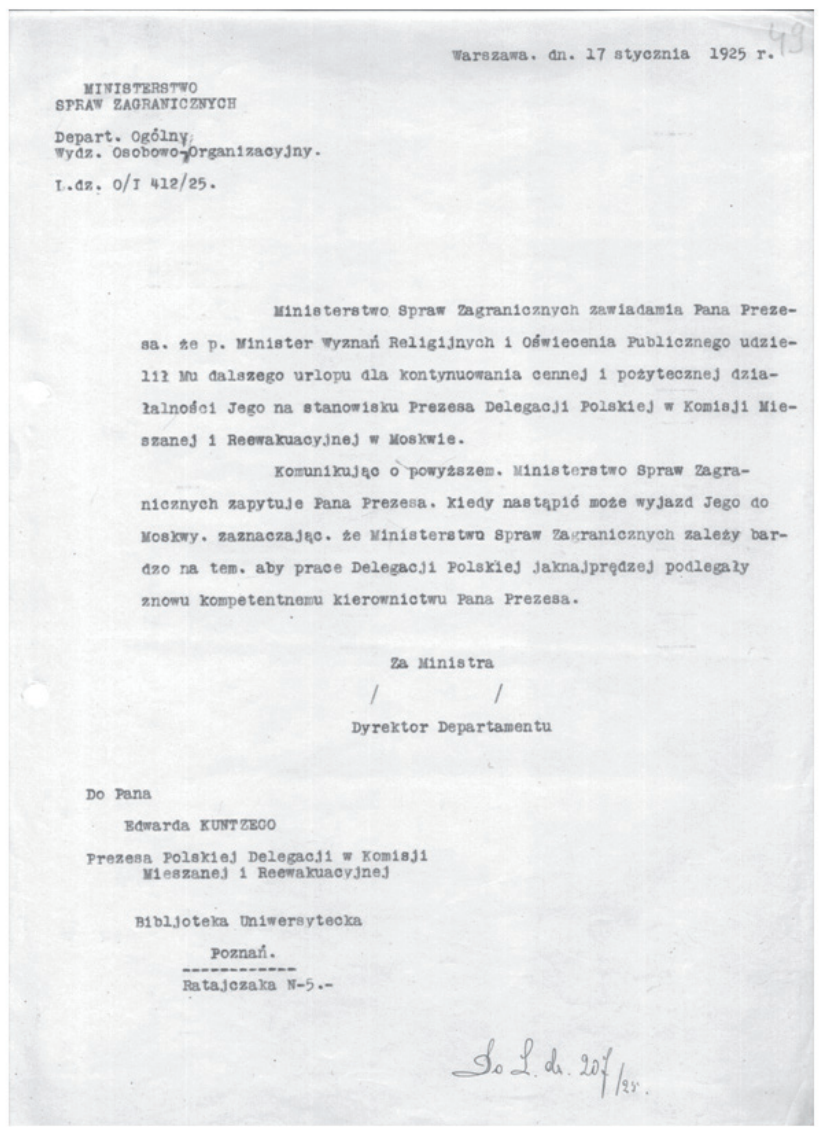

Źródło: Archiwum Biblioteki Uniwersyteckiej w Poznaniu, sygn. 145.

${ }^{18}$ H. Tadeusiewicz: Likowski Henryk [w:] Słownik pracowników książki polskiej. Supl. 1. Warszawa-Łódź 1986, s. 121. 
Po swoim powrocie do kraju E. Kuntze napisał m.in. szkic Zwrot polskich zbiorów bibliotecznych $z$ Rosji, w którym przedstawił rezultaty rokowań w sprawie rewindykacji zagrabionych przez Rosję zabytków bibliotecznych i archiwalnych ${ }^{19}$. Dla oddania trudu i wyrzeczeń w rokowaniach z delegacją sowiecką E. Kuntze przywołuje list Jana Dąbskiego, przewodniczącego delegacji na rokowania pokojowe w Rydze. Dąbski tak scharakteryzował przedstawicieli sowieckich:

(...) społeczeństwo nasze nie zdaje sobie zupełnie sprawy, w jak ciężkich warunkach musi pracować nasza Delegacja. Ma się do czynienia z przeciwnikiem, który nieraz sam się śmieje ze swych «argumentów», który przyznaje się do tego, że zmienia stanowisko, który czasem odwołuje na drugi dzień, co powiedział dnia poprzedniego, który tłumaczy się odmiennością swego ustroju społecznego, który ma całkiem inną moralność aniżeli cały świat, wskutek czego wiele przyrzeczeń i zobowiązań nie przedstawia żadnej wartości, bo mogą być w każdej chwili cofnięte. Trzeba świętej cierpliwości, aby wysłuchać kilkugodzinnych mów delegatów, którzy przytaczają to samo, po 10 razy, aby zmęczyć, zmordować przeciwnika i zmusić do ustępliwości ${ }^{20}$.

Po powrocie z Moskwy, powołano Edwarda Kuntzego na stanowisko dyrektora Biblioteki Jagiellońskiej, natomiast nowym dyrektorem Bibliotece Uniwersyteckiej w Poznaniu został Stefan Vrtel-Wierczyński.

\section{Powrót do Krakowa}

Kraków czekał na Edwarda Kuntzego, który od dawna był prawą ręką dyrektora F. Papéego ${ }^{21}$. W tym okresie najpilniejszym problemem do rozwiązania, od wielu lat bolączką Biblioteki Jagiellońskiej, pozostawała budowa nowego gmachu: „Przenoszono książki z sali do sali, składano na podłodze,

19 „Delegacja Polska w tzw. Komisji Specjalnej zajmowała się odzyskaniem mienia kulturalnego, lecz również Delegacja Polskiej w tzw. Komisji Reewakuacyjnej, której zadaniem było odzyskanie polskiego mienia kolejowego, fabrycznego, rolnego, użytku domowego, szosowo-wodnego itp. (...) czego zwrot w naturze, względnie w niektórych wypadkach ekwiwalencie, przewidywały postanowienia artykułów XIV i XV traktatu ryskiego". Zob.: E. Kuntze, Zwrot polskich zbiorów bibliotecznych z Rosji, Kraków 1937, s. 6.

${ }^{20}$ Tamże, 16-17.

${ }^{21}$ „Był dyrektorowi Papée niezwykle pomocny przy przeniesieniu Biblioteki Jagiellońskiej z dawnego gmachu do świeżo pozyskanego budynku Nowodworskiego, w urządzeniu wypożyczalni, organizowaniu zamawiania książek i czasopism naukowych". Zob.: H. Lipska, Dyrektor Biblioteki Jagiellońskiej Edward Kuntze, dz. cyt., s. 41. 
uniemożliwiało to normalne funkcjonowanie Biblioteki. (...) Collegium Maius nie miało żadnych urządzeń ogrzewczych ani oświetleniowych; poszukiwania książek zimą ograniczały się do godziny 16 . Magazynierzy urzędowali w długich kożuchach z latarkami elektrycznymi”22.

W 1928 roku ówczesny rząd wyasygnował milion złotych na budowę gmachu Biblioteki Jagiellońskiej. Budowę rozpoczęto w 1931 roku. W 1940 roku miało nastąpić uroczyste otwarcie nowego gmachu. Plany te jednak przekreślił wybuch II wojny światowej.

Bibliotekę Jagiellońską Niemcy przekształcili na Staatsbibliothek Krakau, a dyrektorem został Niemiec Abbe, dobrze znający Kuntzego, z którym spotykał się na międzynarodowych zjazdach bibliotekarzy. Dyrektorowi wraz grupą przedwojennych pracowników pozwolono nadal pracować w bibliotece. Starali się oni chronić zbiory przed okupantem, stąd też rola dyrektora była nie do przecenienia:

(...) ci, którzy patrzyli na jego codzienne wysiłki przy ochronie starej i nowej Jagiellonki, widzieli jego zachowanie się wobec Niemców, patriotyzm, odwagę i śmiałość wypowiedzi oraz korzystali z jego pomocy - zachowali dla Edwarda Kuntzego wielki szacunek i wdzięczną pamięć. Za wiedzą dyrektora prawie wszyscy bibliotekarze i kilku starszych w magazynie również pożyczało książki pracownikom naukowym, studentom i uczniom dla tajnego nauczania ${ }^{23}$.

Profesor Stanisław Pigoń tak wspomina ten czas:

Pokaźną bibliotekę seminaryjną odebrano nam w pierwszych zaraz tygodniach (...). Paręnastotysięczny księgozbiór zakładowy bez opieki i dozoru zesypano na stertę i platformami przewieziono do gmachu Biblioteki Jagiellońskiej (...) Polscy gospodarze Biblioteki nie rozerwali wszelako zbioru (....) Dyrektor Kuntze (...) pozwolił mi z niego korzystać, a nawet polecił użyczyć klucza do odpowiedniego skrzydła księgozbioru. Zachodziłem tam przez jakiś czas, by wprowadzać jaki taki porządek, a zarazem wynosić po trosze książki potrzebne naszym kompletom (...) Trwało to do czasu, kiedy nie zaczął węszyć pewien Niemiec. Zwrócono mi uwagę na jednego z nowych woźnych Biblioteki. Był to frant młody, przystojny o lisim, szelmowskim spojrzeniu, bezczelny, rozbijający się zuchwale po instytucji, węszący na prawo i lewo

22 Tamże, s. 43.

23 Tamże, s. 45. 
(...). Jakoż wnet zainteresował się bliżej, po co to ja zachodzę tak często do magazynu i w jakim celu wynoszę książki. Trzeba było zwrócić klucz i urwać wypożyczanie ${ }^{24}$.

W czasie okupacji dyrektor otaczał opieką swoich pobratymców:

Jego troska o ludzi wykraczała i poza bibliotekę. Po powstaniu warszawskim szczególniejszą opiekę okazywał bibliotekarzom ze spalonej stolicy. Sam wyrzucony przez Niemców z dawnego obszernego mieszkania w domu profesorskim (...), zamieszkał w dwóch małych, ciemnych i wilgotnych pokoikach na parterze przy ul. Św. Krzyża ${ }^{25}$.

Powróćmy jednak do początków bibliotekarstwa w II Rzeczypospolitej.

\section{Organizacja biblioteki}

Od momentu odzyskania przez Polskę niepodległości środowisko bibliotek naukowych zastanawiało się, jaki wybrać kierunek rozwoju, jakie zadania wyznaczyć poszczególnym bibliotekom, by stworzyć spójną wizję nowoczesnego bibliotekarstwa, nie wyłączając przy tym idei utworzenia Biblioteki Narodowej.

Edward Kuntze w roczniku 2. „Nauki Polskiej” z 1919 roku opublikował referat zatytułowany Potrzeby polskich bibliotek naukowych, inicjując tym samym ciekawą dyskusję. Przedstawił także zadania stojące przed bibliotekarzami ${ }^{26}$. Postulował przede wszystkim zmianę organizacji oraz stylu pracy bibliotecznej. Pisał: „Nie mamy ani jednej biblioteki, której katalog byłby dla każdego dostępny, a to jest conditio sine qua non biblioteki nowoczesnej"27. Zapowiadał konieczność przeprowadzenia reform. Uważał, że dobry katalog stanowi podstawę swobodnego korzystania z biblioteki, a niesamodzielne wyszukiwanie sygnatur (tylko przez urzędników lub woźnych) jest powodem wielkiego niezadowolenia czytelników. Ganił traktowanie zawodu jako czegoś w zastępstwie: „Prawie każdy z urzędników uważał bibliotekarstwo za zajęcie tymczasowe, jako szczebel do czegoś wyższego, prawie

\footnotetext{
${ }^{24}$ S. Pigoń, Z przędziwa pamięci. Urywki wspomnień, Warszawa 1968, s. 261-262.

25 Twórcy nowoczesnego bibliotekarstwa polskiego, dz. cyt., s. 183.

${ }^{26}$ Z. Gaca-Dąbrowska, Bibliotekarstwo II Rzeczypospolitej. Zarys problemów organizacyjnych i badawczych, dz. cyt., s. 58.

${ }^{27}$ E. Kuntze, Potrzeby polskich bibliotek naukowych, „Nauka Polska” 1919, s. 517.
} 
każdy marzył o profesurze, a co najmniej o docenturze"28. Nie mniejszym złem było liche uposażenie bibliotekarzy. Było to czymś niekorzystnym dla pracy zawodowej, gdyż urzędnicy, aby utrzymać rodziny, musieli zarobkować poza biblioteką. Te i inne zagadnienia stanowily pewnego rodzaju deklarację programową dla wszystkich, którym zależało na zmianach. Reorganizacja i szkolenia stały się zadaniami podstawowymi dla bibliotek naukowych, by te w pełni mogły być warsztatami wszelkiej pracy naukowej. Jednocześnie troska o godziwe życie bibliotekarzy i uznanie ich pasji, zaangażowania, wiedzy oraz kompetencji zawodowych stały się podstawą dobrego funkcjonowania biblioteki.

E. Kuntze prowadził również niełatwą pracę redaktora „Przeglądu Bibliotecznego”. Pieczę nad całością sprawował od 1927 roku, czyli od początku istnienia pisma, aż do 1947 roku.

Mimo ciężkich warunków powojennych już w roku 1946 przystąpił Kuntze do kontynuowania «Przeglądu Bibliotecznego», zdając sobie sprawę z tego, że żywiołowy pęd do tworzenia bibliotek (...) wymaga przedyskutowania na łamach fachowego organu $(\ldots)^{29}$.

Po śmierci redaktora znaleziono jego odręczne notatki przy każdym niemal nadesłanym tekście. Wszystkie problemy bibliotekarskie, nad którymi publicznie dyskutowano, znajdowały swoje odzwierciedlenie na łamach „Przeglądu Bibliotecznego" 30 .

\section{Jakim człowiekiem był dr Edward Kuntze?}

„Dyrektor Kuntze zawsze spieszył z pomocą swoim pracownikom, miał duże zrozumienie dla ich pracy naukowej, byleby nie kolidowała $\mathrm{z}$ zajęciami bibliotecznymi - pomagał i zachęcał" ${ }^{31}$. Jego elegancja i sposób bycia nie przytłaczały, wręcz przeciwnie dyrektor przyciągał ludzi swoją prostolinijnością, każdy z pracowników odczuwał jego życzliwość.

\footnotetext{
28 Tamże.

${ }^{29}$ J. Baumgart, Edward Kuntze jako bibliotekarz, dz. cyt., s. 27.

30 H. Lipska, Dyrektor Biblioteki Jagiellońskiej Edward Kuntze, dz. cyt., s. 47.

31 Tamże, s. 45.
} 


\section{Il. 5. Fotografia Edwarda Kuntzego}

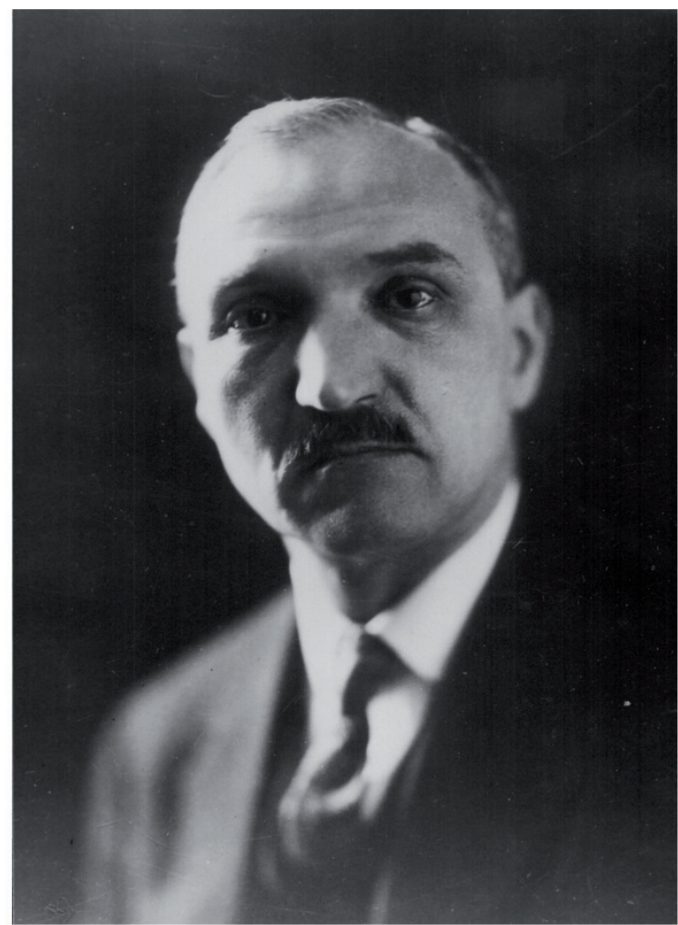

Źródło: Archiwum Biblioteki Uniwersyteckiej w Poznaniu, sygn. 2184.

Wytworna postać dyrektora Kuntzego, zawsze w ciemnym wizytowym garniturze ze starannie zawiązaną muszką, jego takt i maniery dyplomaty wywierały mimo woli wpływ na całe otoczenie, na spokój i harmonię w stosunkach międzyludzkich, na wzajemną życzliwość i koleżeństwo bez poufałości, na docenianie każdej pracy na wszystkich szczeblach służbowych, na wzajemną pomoc w rozwiązywaniu bardziej skomplikowanych zagadnień bibliotecznych. Ostateczną instancją był zawsze sam dyrektor ${ }^{32}$.

Szukano jego rady i pomocy, nawet gdy już wyjechał do Moskwy i potem, kiedy piastował funkcję dyrektora w Krakowie, wspomina Jan Baumgart, pracownik Biblioteki Uniwersyteckiej w Poznaniu i Krakowie, a po wojnie dyrektor Biblioteki Jagiellońskiej³.

${ }^{32}$ Twórcy nowoczesnego bibliotekarstwa polskiego, dz. cyt., s. 165-166.

33 J. Baumgart, Działalność Edwarda Kuntzego na stanowisku Dyrektora Biblioteki Uniwersyteckiej w Poznaniu, Zakład Narodowy im. Ossolińskich, Warszawa 1957, s. 111. 
Jego [E. Kuntzego] niezwykłą postać mogłem ocenić podczas okupacyjnej nocy, gdy byłem jednym z najbliższych współpracowników. Ten okres wspólnej pracy pod jego kierunkiem dał mi ten sam podziw dla szerokiej jego wiedzy bibliotekarskiej, uczucie głębokiej wdzięczności i szacunku dla wszystkich jego wartości oraz zrozumienie czci i przywiązania, jakie zaskarbił sobie w gronie swoich współpracowników, jako pierwszy polski dyrektor Biblioteki Uniwersyteckiej w Poznaniu ${ }^{34}$.

\section{STEFAN VRTEL-WIERCZYŃSKI (1886-1963)}

\section{Działalność patriotyczna (1905-1945)}

Stefan Vrtel-Wierczyński pochodził z rodziny czesko-morawskiej, osiadłej w byłej Galicji w drugiej połowie XIX wieku. „11 maja 1919 Stefan Vrtel uzyskał zgodę od galicyjskiego namiestnictwa na zmianę rodowego nazwiska Vrtel na Wierczyński i od tego czasu używał na ogół tego drugiego"35. W Stryju, gdzie uczęszczał do gimnazjum klasycznego, po złożeniu matury w 1905 roku, wstąpił na Uniwersytet Jana Kazimierza. W gimnazjum należał do tajnej organizacji niepodległościowej młodzieży gimnazjalnej. Gdy miał 18 lat, zorganizował w Stryju Koło Młodzieży Patriotycznej i był jego przewodniczącym.

W 1914 roku, po wybuchu I wojny światowej, został powołany w stopniu adiutanta brygady do Legionu Wschodniego; po jego rozwiązaniu - razem z Władysławem Semkowiczem - stworzył w 1915 roku, najpierw we Lwowie, a następnie w Warszawie, Polskie Archiwum Wojenne ${ }^{36}$. PAW było instytucją naukową, która za cel stawiała sobie gromadzenie materiałów archiwalnych i muzealnych dotyczących udziału Polaków w I wojnie oraz sytuacji politycznej, gospodarczej, społecznej Polski i Polaków ${ }^{37}$.

Stefan Vrtel, przydzielony do Komendy Miasta i Placu Lwów, służył w szeregach wojska do 1919 roku. W okresie II wojny światowej działał w Podziemnym Ośrodku Bibliotek Naukowych (ratowano księgozbiory, ukrywając te cenniejsze, rejestrowano zniszczenia dokonywane przez okupantów, rozwijano działalność kulturalną w warunkach okupacyjnych). Czuwał nad

\footnotetext{
${ }^{34}$ Tamże.

${ }_{35}$ M. Stasiewska, Życie, działalność i twórczość prof. Stefana Vrtél-Wierczyńskiego, Praca magisterska, Instytut Bibliotekoznawstwa i Informacji Naukowej UAM w Poznaniu, 1977, mps, s. 11.

36 Tamże, s. 14.

37 Tamże.
} 


\section{Il. 6. Fotografia Stefana Vrtela}

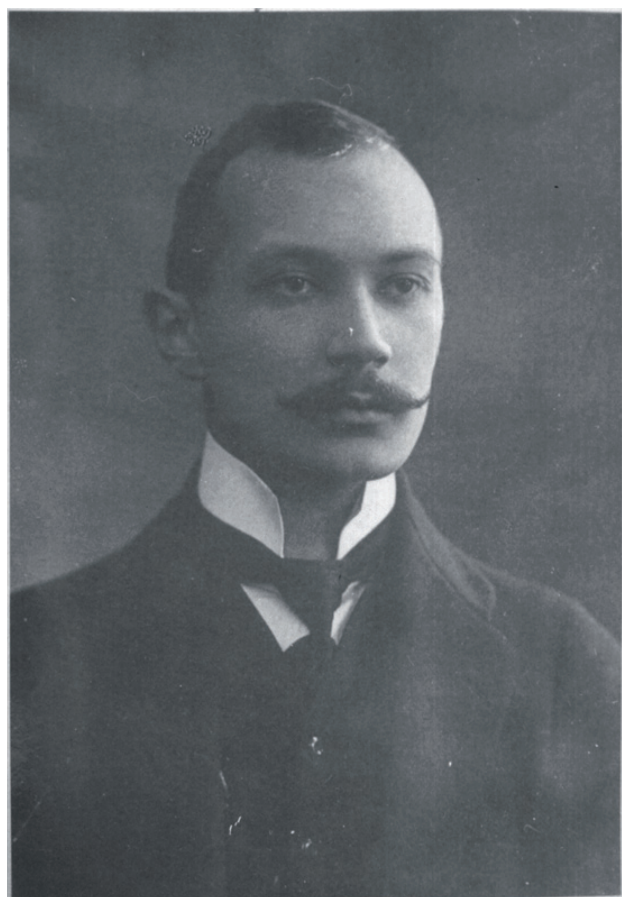

Źródło: Archiwum Biblioteki Uniwersyteckiej w Poznaniu, sygn. 2184.

Biblioteką Narodową i starał się nią kierować, nawet gdy Niemcy wyrzucili go stamtąd w 1940 roku. Jeszcze przed wojną, latem 1939, Wierczyński, będąc dyrektorem Biblioteki Narodowej, zarządził, by zbiory specjalne wywieziono do kazamatów Fortu Sokolnickiego na Żoliborzu, które przygotowywano już od wiosny ${ }^{38}$. Zbiory te szczęśliwie przetrwały wojnę. Biblioteka Narodowa poniosła jednak znaczne straty. Jak pisze S. Wierczyński - „bezcenne rękopisy raperswilskie i Załuskich, ocalałe na fortach w czasie oblężenia Warszawy we wrześniu 1939 r., spalili Niemcy najokrutniej i z premedytacją po powstaniu w listopadzie 1944 r. w gmachu Biblioteki Krasińskich przy okólniku”39. Zabytki najcenniejsze (m.in. „Psałterz floriański”, „Kazania świętokrzyskie”, pergaminowe księgi iluminowane, rękopisy muzyczne Chopina) zdeponowano w sierpniu 1939 roku w kasach pancernych Banku Gospodarstwa Krajowego, skąd zostały wywiezione we wrześniu do

38 Tamże, s. 18.

39 Cyt. za: T. S. Grabowski, Pożegnanie z profesorem Uniwersytetu Poznańskiego Stefanem Vrtélem-Wierczyńskim (1886-1963), Poznań 1963, s. 7. 


\section{7. Profesor Stefan Wierczyński}

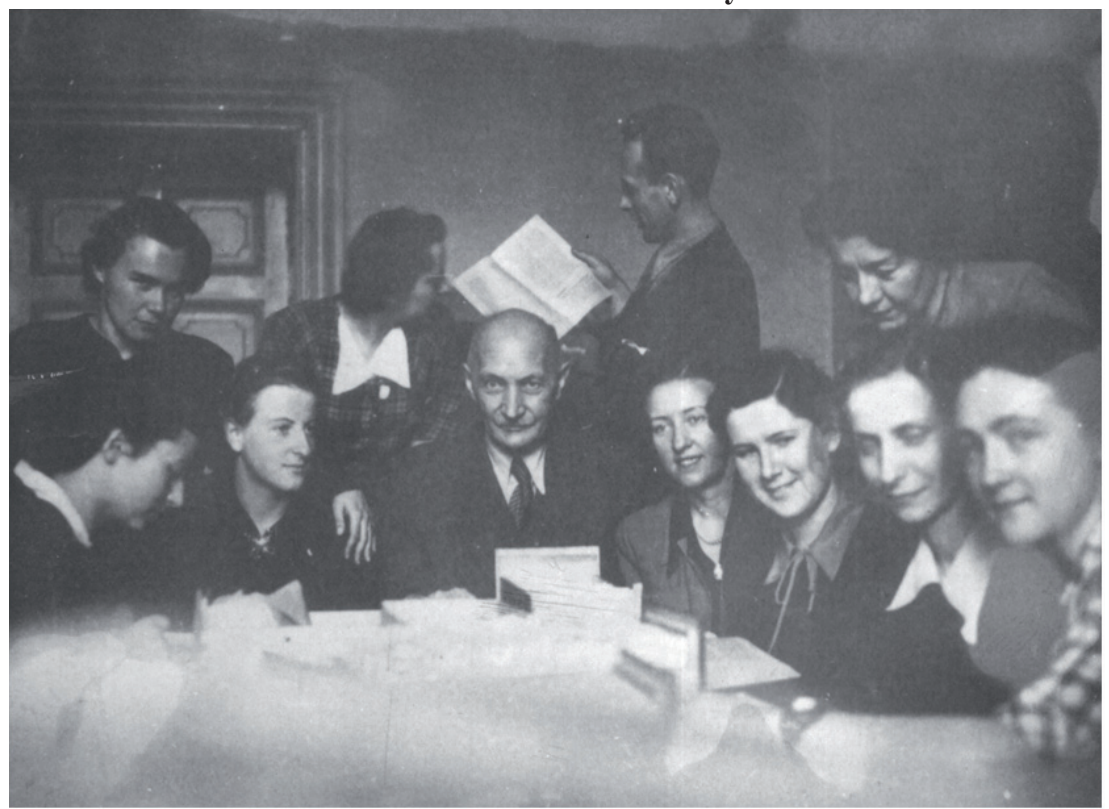

Źródło: Archiwum Biblioteki Uniwersyteckiej w Poznaniu, sygn. 2184.

Kanady (Bank of Montreal w Ottawie). Do Biblioteki Narodowej wróciły w roku $1959^{40}$. We wrześniu 1939 roku Niemcy zażądali natychmiastowego wydania cymeliów. Zaczęło się więc śledztwo, w konsekwencji którego aresztowano dyrektora i kustosza Działu Rękopisów Biblioteki Narodowej. Profesor był jeszcze dwukrotnie aresztowany i dwukrotnie zwalniany, podczas powstania warszawskiego przebywał na Żoliborzu, a następnie - po przymusowym wysiedleniu do Pruszkowa - w Krakowie, gdzie wykładał na tajnych kompletach uniwersyteckich w ramach Uniwersytetów Warszawskiego i Poznańskiego. Profesor uczył prawie całe życie, jego praca zawodowa przeplatała się z dydaktyczną. Był cierpliwym i mądrym nauczycielem. Nad teorię przedkładał ćwiczenia. W gimnazjum we Lwowie uczył niemal dziesięć lat (1909-1918), a od roku 1924 wykładał bibliografię i bibliotekoznawstwo na Uniwersytetach Lwowskim i Poznańskim (w czasie okupacji na tajnych kompletach). W 1956 roku uzyskał tytuł profesora zwyczajnego.

Jak podkreślają biografowie S. Vrtela-Wierczyńskiego, właściwie aż do śmierci prowadził swoją działalność naukową i dydaktyczną. A śmierć... zastała profesora nad książką.

\footnotetext{
40 B. Świderski, Stefan Vrtél Wierczyński 1886-1963, Warszawa 1963, s. 13.
} 


\section{Pasja bibliograficzna}

Do tradycji Zakładu Ossolińskich we Lwowie należało przyznawanie stypendiów. Jego beneficjentem był również Stefan Vrtel, który jako student filologii polskiej, słowiańskiej i klasycznej Uniwersytetu Lwowskiego, korzystał z stypendium Zakładu Narodowego im. Ossolińskich w latach 1906-1908. Praktyka w Bibliotece Zakładu Ossolińskich stała się inspiracją i modus vivendi: „Dzień 1 lutego 1906 miał dla mnie znaczenie bardzo doniosłe. Nie tylko doraźne, lecz także głębsze, zasadnicze, sięgające w bardzo daleką przyszłość" ${ }^{41}$. W czasie praktyk zaproponowano mu udział w opracowaniu bibliografii literackiej. Sam Wierczyński pisał we wspomnieniach: „prymicje bibliograficzne odbyte w murach zakładu były pierwszym bodźcem, który przerodził się w trwałą predylekcję i zamiłowanie” ${ }^{42}$. Rzeczywiście, „prymicje bibliograficzne" odbyły się bardzo szybko, bo jeszcze podczas trwania ossolińskich praktyk. W 1907 roku ukazała się Bibliografia historii literatury i krytyki literackiej za rok 1905 - dodatek do „Pamiętnika Literackiego" ${ }^{3}$. Stefan Wierczyński uważał ossolińskie praktyki za podstawę zainteresowań naukowych, którym był wierny przez całe życie: „Był jeszcze jeden dział w Ossolineum, który żywo mnie interesował: Slawistyka-bohemistyka i rusycystyka" ${ }^{44}$. Młodego dr. Vrtela zajmowała także organizacja bibliografii. Już w 1917 roku ukazała się praca zatytułowana: Organizacja bibliografii. $W$ sprawie Polskiego Instytutu Bibliograficznego. Stefan Vrtel wysunął projekt stworzenia Instytutu Bibliograficznego, który systematycznie i w sposób zorganizowany kierowałby pracami bibliograficznymi w Polsce. Dotychczas bibliografia, jako dziedzina nauki, miała raczej charakter jednostkowy i okazjonalny. Vrtel chciał stworzyć samoistną dyscyplinę naukową, a także jednostkę nadzorującą takie badania. „Sprawy te wiązały się z ogólną polityką organizacji bibliografii w Polsce. I w tych kwestiach, obok S. Vrtela, zabierali głos Muszkowski, Jarkowski i inni ${ }^{45}$. S. Vrtel, będąc teoretykiem i praktykiem, zabiegał również o stworzenie bibliografii literackiej retrospektywnej. I ten zamysł profesora (podobnie jak powołanie Polskiego Instytutu Bibliograficznego) został zrealizowany dopiero po II wojnie, gdy w Poznaniu rozpoczęła swoją działalność Pracownia Bibliograficzna przy Instytucie Ba-

\footnotetext{
${ }^{41}$ Cyt. za: J. Baumgart, Działalność prof. Stefana Vrtela-Wierczyńskiego w zakresie bibliografi, „Roczniki Biblioteczne” 1984, z. 1-2, s. 42.

42 Tamże, s. 43.

${ }^{43}$ Tamże.

44 Tamże.

${ }^{45}$ Tamże, s. 8.
} 
dań Literackich. Jan Baumgart, uczestnik sesji zorganizowanej w Poznaniu w 1983 roku dla uczczenia dwudziestej rocznicy śmierci profesora, swoim referatem zaświadczył o wyjątkowości uczonego: „(...) prof. Stefan Vrtel-Wierczyński pozostanie uczonym, który w historii polskiej bibliografii był twórcą bibliografii ogólnej i regionalnej, bibliografii specjalnej oraz bibliografii zawartości czasopism" 4 .

\section{Z Lwowa do Poznania (1927-1937, 1947-1950)}

W roku 1927 dr Stefan Wierczyński wszedł w zupełnie nowe środowisko o skrajnie odmiennej mentalności; lwowiak przeobraził się w poznańczyka. Opuszczał Lwów dla Poznania, obejmował bowiem stanowisko dyrektora Biblioteki Uniwersyteckiej. Była to z pewnością trudna decyzja i nie lada wyzwanie. Praca w Lwowskiej Bibliotece Uniwersyteckiej stanowiła początek wielkiej pasji bibliograficznej i bibliotekarskiej oraz kariery na uczelni ${ }^{47}$, była czasem spotkań w Związku Bibliotekarzy Polskich (Vrtel-Wierczyński należał do zarządu Koła). Krystyna Remerowa, bliska koleżanka z czasów lwowskich, tak wspomina pożegnanie S. Wierczyńskiego:

W 1927 roku pożegnaliśmy uroczyście naszego kustosza (...). Żegnaliśmy go z prawdziwym żalem, choć zdawaliśmy sobie sprawę, że dla jego zainteresowań słowianoznawczych związanych ze średniowieczną literaturą polską, praca w środowisku poznańskim otwierała nowe możliwości ${ }^{48}$.

Staraniem dyrekcji w 1929 roku powstało Towarzystwo Przyjaciół Biblioteki Uniwersyteckiej w Poznaniu, którego członkowie współfinansowali zakup lub sami kupowali cenne książki, które następnie przekazywali bibliotece. Konieczne stało się dalsze spolszczenie księgozbioru. „Apel Dyrekcji, ogłoszony w prasie miejscowej, a przedstawiający potrzeby księgozbioru, wywołał żywy oddźwięk wśród sfer kulturalnych i naukowych"49. Potem nastąpiła wewnętrzna reorganizacja BU. W dawnej sali wykładowej utwo-

\footnotetext{
46 Tamże, s. 53.

47 „W roku 1923 habilitował się na uniwersytecie Jana Kazimierza we Lwowie z nauk pomocniczych literatury (bibliografii i bibliotekoznawstwa), a w roku 1927 rozszerzył habilitację na historię literatury polskiej ze szczególnym uwzględnieniem jej stosunku do literatury czeskiej”. T. S. Grabowski, Pożegnanie z profesorem Uniwersytetu Poznańskiego Stefanem Vrtelem-Wierczyńskim (1886-1963), dz. cyt., s. 6-7.

48 Twórcy nowoczesnego bibliotekarstwa polskiego, dz. cyt., s. 315-316.

49 Sprawozdanie Dyrekcji Biblioteki na rok 1928/1929, Poznań, s. 9, mps.
} 
rzono czytelnię czasopism. Trzeba przyznać, że prof. Stefan Wierczyński był znakomitym menadżerem, umiejącym zadbać o dobro Biblioteki Uniwersyteckiej, ale i zaktywizować środowisko wielkopolskie. Do Towarzystwa Przyjaciół Biblioteki Uniwersyteckiej w Poznaniu należeli bowiem ziemianie i inteligencja wielkopolska: prof. Ludwik Ćwikliński (wówczas minister), prof. Tadeusz Grabowski, red. W. Noskowski, hr. Rogher Raczyński i inni.

Kolejną inicjatywą dyrektora było opublikowanie w 1930 roku Centralnego Katalogu Czasopism i Wydawnictw Ciagtych znajdujących się w bibljotekach poznańskich. Katalog ten obejmował 98 bibliotek: Bibliotekę Towarzystwa Przyjaciół Nauk, Raczyńskich, Radziecką, Wyższej Szkoły Handlowej i in. ${ }^{50} \mathrm{i}$ tym samym otwierał się na środowisko zawodowe oraz odwrotnie: dawał szansę na bliższe poznanie się i wymianę doświadczeń bibliotecznych. Ostatecznie informacja, którą przekazywano czytelnikom, była pełniejsza, a to przecież było celem nadrzędnym. Drugim ważnym działaniem była konsolidacja zawodowa. Równolegle trwały przygotowania do kolejnego Zjazdu Bibliotekarzy ${ }^{51}$. Referat Polityka biblioteczna w zakresie czasopism naukowych, wygłoszony na III Zjeździe Bibliotekarzy Polskich w Wilnie w 1932 roku, dotyczył właśnie roli czasopism naukowych, tworzenia katalogów centralnych, obejmujących swym zasięgiem cały kraj. Projekt stworzenia centralnego katalogu czasopism i wydawnictw ciągłych w bibliotekach w Polsce wywołał dyskusję i powszechną zgodę związkowców ZBP. Biblioteka Uniwersytecka w Poznaniu, pod kierownictwem S. Wierczyńskiego, zajęła się tworzeniem Centralnego Katalogu Czasopism Zagranicznych znajdujących w bibliotekach Rzeczypospolitej Polskiej. Pomysł ten zyskał aprobatę Ministerstwa Wyznań Religijnych i Oświecenia Publicznego oraz przedstawicieli Funduszu Kultury Narodowej ${ }^{52}$. W Bibliotece Uniwersyteckiej w Poznaniu znajdowało się centrum koordynacyjne, pozostałe biblioteki uniwersyteckie zbierały informacje o czasopismach w swoim regionie i materiały przesyłały do centrali ${ }^{53}$.

50 Sprawozdanie Biblioteki Uniwersyteckiej na rok 1936/37, Poznań, s. 82, mps.

${ }^{51}$ Ogólnopolskie zjazdy bibliotekarzy poprzedzały spotkania bibliofilskie, będące ważnym wydarzeniem. I Zjazd Bibliofilów odbył się w Krakowie w 1925 roku, II - rok później w Warszawie. Z czasem bibliotekarze organizowali własne zjazdy. Odbywały się one co dwa, trzy lata. Pierwszy odbył się we Lwowie w 1928 roku, drugi w Poznaniu w 1929 roku, trzeci w Wilnie w 1932 roku, czwarty natomiast w Warszawie w roku 1936. Zob.: Z. Gaca-Dąbrowska, Bibliotekarstwo II Rzeczypospolitej. Zarys problemów organizacyjnych i badawczych, dz. cyt., s. 53-54.

${ }_{52}$ M. Stasiewska, Życie, działalność i twórczość prof. Stefana Vrtel-Wierczyńskiego, dz. cyt., s. 69.

53 S. Vrtel-Wierczyński, Polityka biblioteczna w zakresie czasopism naukowych, „Przegląd Biblioteczny" 1932, s. 128-131. 


\section{Il. 8. Korespondencja w sprawie Centralnego Katalogu Czasopism Zagranicznych, marzec 1939}
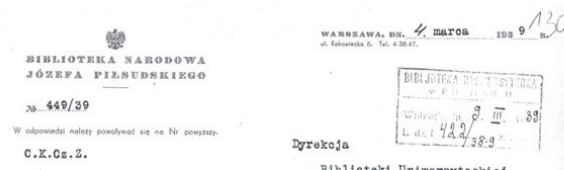

B1b110tek1 Uniwerayteokiej

$$
\text { Pognan }
$$

70dpowiedzi na p1smo z ania 10.Ir.1939, 1.dz. I.372/38-9, Dyrokoja Biblioteki larodowej Józefa Piłeudakiogo potwlerdza z podz1ękowan1em odb16r w dnIu 1 b.m. zapow1odzlanos w powyzsays pímlo okrzyn1, zawlerajaooj 9 pudez kart anall tyoznyoh / 11tera "B"- 7, "C" - 2/ Centralnego Katalogu Czasopian zagranioznyoh, 1 pudzo odnoányoh kart syntetyoznyoh, 1 puderko kartotek1 ozasop1am szozatkowyoh oras tokę akt dotyozqoyoh komasaoj1.

Stwierdzamy pray tym, ze $w$ wymlenlonyoh aktach brax podanes w spisie 1.dz. 217/36-7; O dostarozenie tego aktu prosimy. zapytu jemy naatẹpnie, k1edy mniej w1ęooj można oozek1wac materlazu anal1 tyoznogo wraz z opracowanlem ayntetyoznym 11ter " $\mathrm{B}$ " $1 \mathrm{man}$.

Przy sposobnośo1 zaznaozany równiez, 2e akta kontynuaof1 c.z.cz.z., przesłane przy p16m10 z đn1a 20.xII.1938, 1.dz. I.

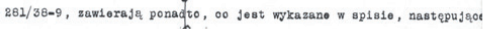
akta:

z r. $1934 / 5$ 1.dz. 1252

z r. $1937 / 8$ 1.dz. $427,481,849,659,689,6131813$.

Brak równ1ez dotyohozas akt kontynuaoysayoh a r. 1933/4. Proel. Wrevermill

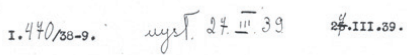

Dyzolo ja Bibliotelici Iarodowaj \#arazama

"1" p1 1́m10 \& an1a 4 maroa b.r.,nr.449/39,

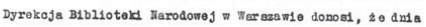
1 m a r O a b.r. debraza akrzynle zamierająoq "9 pudez kart anal1tyoznyoh (11 tera B-7, C-2) Contralnogo Katalogu Czasopion zagran1oznych, I puazo od noónyoh lart ayntetyoznyoh, 1 pudzo kartotek1 oz asopies azczątkonych, oraz teksq akt dotyozqay oh korasacj1". Pakt ten zdz1miz Redakoje, gdyz airrayna zostaza myezana a Poznanta dnia ll 1 u t e $g$ o, Jak togo dowodz1 11at przewozony firmy Hartmig. Przesyzka dotarła więo do "aresany dop1ero po 18 dn1 ach! Pon1ewat prasagy kd $z$ Pozman1a do Warezamy $1 A_{q}$ - Jak nae koloj 1nformujo - nomalnio $2-3 \mathrm{dn} 1$, proa1my o atwierdzenie: 1) dokzadnej daty nadefáo1a akrzyn1 do B1blioteld Narodomej, oraz 2) ozy przesyrka byia nleuszkodzons.

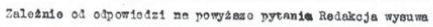
Am10 moß11wo stórym Dyrekoja donos1: 1) p1smo zaginęio m czasie transporta kolejomogo, 2) O 110 skrzynia doezła $w$ normalnym terminie pismo mua1 al ą znajdowaó w B1bl. Narodowej u oвô, u któryoh praoaylka by3a w ozaa1e od 25 lutogo do dn1a 2 maroa, (t.j.đzień

„W drugiej połowie 1934 r. wpłynęły do redakcji materiały z ca 700 bibliotek, liczące przeszło 100.000 kartek" $^{54}$.

Opracowanie takiego katalogu wymagało nakładu olbrzymich sił i pieniędzy. Częściowo zachowana korespondencja z pierwszych miesięcy 1939 roku między BU w Poznaniu a BN potwierdza niewyobrażalny nakład pracy, jakiego wymagało przygotowanie poszczególnych liter katalogu. W związku z nominacją S. Wierczyńskiego na dyrektora Biblioteki Narodowej, utworzono tam oddział CKCzZ. Zachowana w Archiwum Biblioteki Uniwersyteckiej w Poznaniu korespondencja z marca 1939 roku między Stefanem Wierczyńskim, już wtedy dyrektorem Biblioteki Narodowej, a prof. Józefem Bossowskim, p.o. Kierownika i Kuratorem, w sprawie problemów z przesyłką pudeł liter B-7 i C-2 doskonale dokumentuje wspomniane trudności.

${ }^{54}$ J. Miśkowiak, Centralny Katalog Czasopism Zagranicznych znajdujących się w bibliotekach polskich, „Przegląd Biblioteczny” 1935, s. 146. 


\section{Il. 9. Dyrektor Stefan Wierczyński w Bibliotece Uniwersyteckiej w Poznaniu}

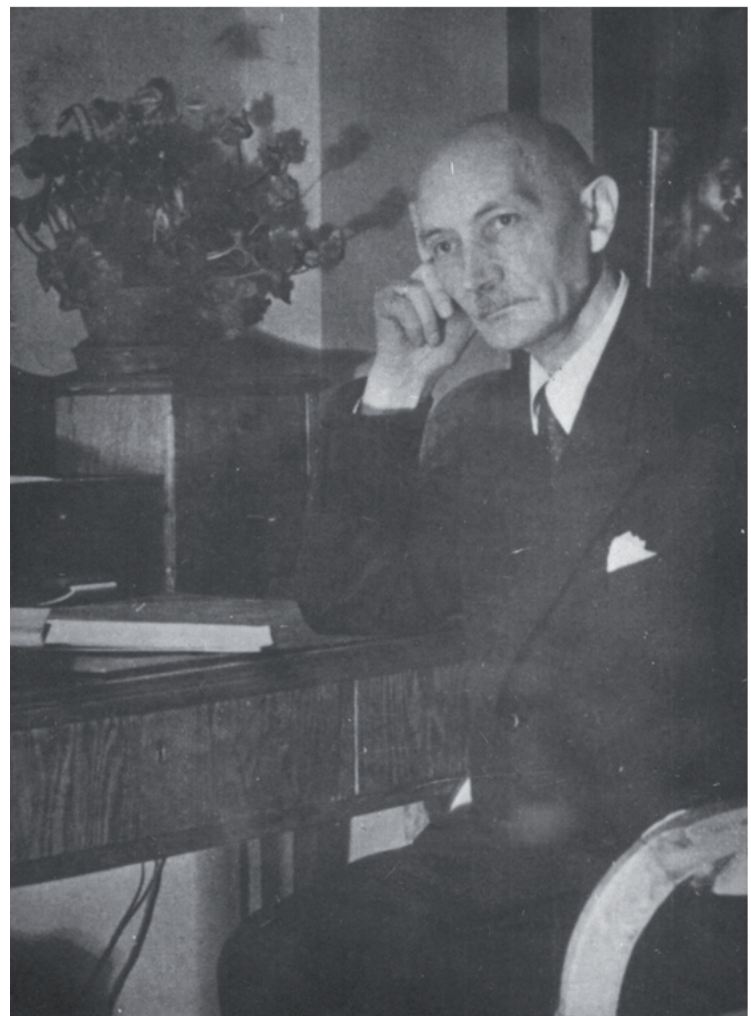

Źródło: Archiwum Biblioteki Uniwersyteckiej w Poznaniu, sygn. 2184.

Wojna zniszczyła i projekt, i ogromny wysiłek twórców Centralnego Katalogu Czasopism Zagranicznych w bibliotekach II RP, ale nie ideę i zapa ${ }^{55}$.

Można śmiało powiedzieć, że prof. Stefan Wierczyński - dzięki swojej wiedzy i mądrym inicjatywom na szczeblu ogólnopolskim czy na gruncie poznańskim - zapisał się mocno w pamięci świata bibliotekarskiego, i nie tylko. Na sesji w 1983 roku w Poznaniu, upamiętniającej osobę i życie profesora, Jan Baumgart nazwał go mistrzem i tym, który dawał z siebie wszystko, ale i umiał wymagać od tych, od których mógł ${ }^{56}$.

55 „Trzydziestoletnie wysiłki bibliotekarstwa polskiego, by dać właściwy informator o naszych zbiorach czasopism, nareszcie osiągają pewien kształt realny w postaci wydawnictwa”. Zob.: Wstęp [w:] Centralny Katalog Bieżących Czasopism Zagranicznych w Bibliotekach Polskich, Warszawa 1957.

56 J. Baumgart, Działalność prof. Stefana Vrtéla-Wierczyńskiego w zakresie bibliografii, dz. cyt., s. 53. 


\section{ALEKSANDER LUDWIK BIRKENMAJER (1890-1967)}

\section{Życiorys}

Aleksander Ludwik Birkenmajer ${ }^{57}$ przyszedł na świat w 1890 roku. Po swoim ojcu, Ludwiku Antonim, odziedziczył imię, po dziadku - Franciszku Karlińskim, także profesorze Uniwersytetu Jagiellońskiego - zamiłowanie do astronomii. Studiował matematykę i fizykę na Wydziale Filozoficznym UJ. Rok po zakończeniu studiów obronił doktorat $\mathrm{z}$ historii astronomii, habilitował się z historii nauk ścisłych w 1929 roku, mając niespełna 40 lat, a w roku 1937 zdobył tytuł naukowy z bibliotekoznawstwa. Często wyjeżdżał za granicę, początkowo z ojcem, który jako wolontariusz „kopernikański” zbierał materiały o Koperniku. Później jeździł sam, poznając przy tym szereg bibliotek europejskich (ponad trzydzieści). Zbierał dokumenty źródłowe do swoich prac, zapoznawał się z zasobami rękopiśmiennymi. Krótko uczył w gimnazjum, po zdaniu egzaminu państwowego na Uniwersytecie we Lwowie w 1918 roku został nauczycielem mianowanym. Był wykładowcą na Uniwersytecie Jagiellońskim, prowadził zajęcia $z$ historii nauk ścisłych, a od roku 1938 również ze wstępu do bibliotekarstwa. Otrzymał tytuł prof. nadzwyczajnego.

Po II wojnie światowej został mianowany profesorem zwyczajnym i w 1951 roku objął Katedrę Bibliotekoznawstwa na Uniwersytecie w Warszawie. Kiedy po pięciu latach pracy w Bibliotece Jagiellońskiej został kierownikiem Działu Rękopisów, był młodym człowiekiem ze sporym stażem naukowym i pedagogicznym. Zgłosił swoją kandydaturę na stanowisko dy-

${ }^{57}$ Pradziad Aleksandra Birkenmajera przybył do Polski ze Schwarzwaldu z Napoleonem i Legionami Dąbrowskiego; stąd wyruszył wraz z bratem na wyprawę moskiewską. Ranny pod Berezyną, pozostał w Galicji, potem ożenił się z Polką i dał początek polskiej linii Birkenmajerów. „Płynęła w żyłach Birkenmajerów kropla krwi niemieckiej. To dzięki fuzji niemieckiego pedantyzmu i sarmackiej fantazji dzieje nauki polskiej zostały wzbogacone o indywidualności tej miary, co Samuel Bogusław Linde, Karol Estreicher, Oskar Kolberg czy Karol Szajnocha”. Zob.: J. Kapuścik, Profesor ze wspomnień ucznia, „Przegląd Biblioteczny” 1978, nr 2, s. 175. Podczas ostatniej wojny, mimo niemieckiego nazwiska, żadnemu z Birkenmajerów przez myśl nie przeszło zostać volksdeutschem. Por. http://forumakad.pl/archiwum/99/9/artykuly/21-rody_uczone. htm, [dostęp: 7.06.2013]. Zob.: też Polski słownik biograficzny, t. 2, Kraków 1936, s. 102-104.

Aleksander Birkenmajer miał dziesięcioro rodzeństwa. Jednym z jego braci był Józef Birkenmajer, polski slawista, historyk literatury, poeta, tłumacz. Przed wybuchem drugiej wojny jako profesor przebywał w Stanach Zjednoczonych, wrócił do kraju w 1939 roku. Zginął w wojnie obronnej we wrześniu 1939. Książki tłumaczone przez Józefa Birkenmajera: „Mała księżniczka Francesa Hodgsona Burnetta, „Księga dżungli” Rudyarda Kiplinga czy „Przypadki Robinsona Crusoe" Daniela Defoe są jak uśmiech dzieciństwa. 
Il. 10. Profesor Aleksander Birkenmajer z córką Marysią, lata 50. XX wieku

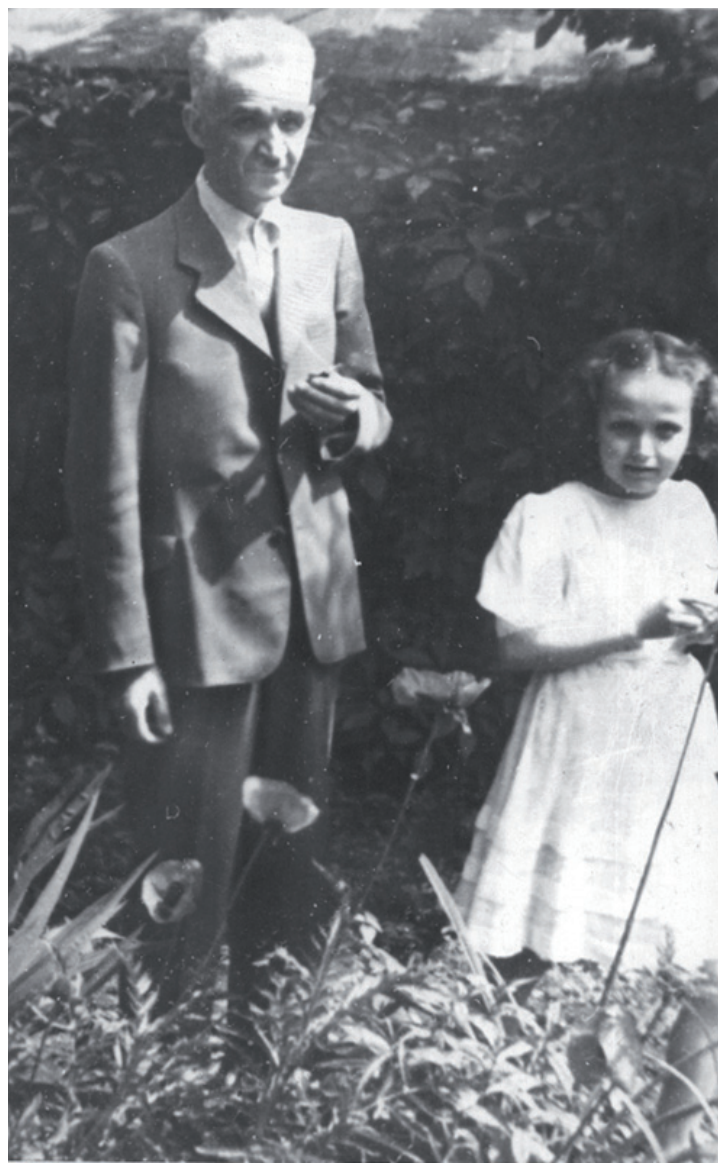

Źródło: Archiwum Biblioteki Uniwersyteckiej w Poznaniu, sygn. 2184.

rektora poznańskiej Biblioteki Uniwersyteckiej, które do marca 1937 roku piastował prof. Stefan Wierczyński, późniejszy dyrektor Biblioteki Narodowej. Edward Kuntze w piśmie do Senatu Uniwersytetu Poznańskiego informował:

Uważam dra Birkenmajera za jednego z najwybitniejszych bibliotekarzy polskich, posiadającego nie tylko wszechstronne i bardzo poważne teoretyczne wykształcenie w zakresie bibliotekoznawstwa, lecz także długoletnie doświadczenie we wszystkich działach praktyki bibliotekarskiej. (...) trzeźwy pogląd na sprawy, planowość i systematyczność w pracy, umiejętność obchodzenia się z podwładnym personelem, rzeczowy stosunek do korzystających, 
znajomość obcych języków w mowie i piśmie, możność naukowego, fachowego reprezentowania Biblioteki w kraju i zagranicą kwalifikują dra Birkenmajera, moim zdaniem już dawno, na kierownika wielkiej biblioteki naukowej ${ }^{58}$.

Ostatecznie Aleksander Birkenmajer objął kierownictwo w Bibliotece Uniwersyteckiej w Poznaniu pod koniec marca 1939 roku. Po wybuchu wojny udał się na wschód, na Polesie, ponieważ groziło mu niebezpieczeństwo; wcześniej prowadził bowiem publiczną polemikę z niemieckim docentem Hansem Schmauchem na temat polskości Kopernika ${ }^{59}$. Po wkroczeniu Rosjan, 17 września, Birkenmajer wrócił z rodziną przez Poznań do Krakowa. Bibliotekę Uniwersytecką w Poznaniu zamknięto, podobnie zresztą jak Bibliotekę Poznańskiego Towarzystwa Przyjaciół Nauk czy Bibliotekę Raczyńskich. Mieszkanie Aleksandra Birkenmajera zostało zapieczętowane, a mienie skonfiskowane.

\section{Okupacja w Krakowie}

Na początku listopada Aleksander Birkenmajer zgłosił się do pracy w Bibliotece Jagiellońskiej. Biblioteka funkcjonowała normalnie, 19 października Senat postanowił bowiem otworzyć uniwersytet i rozpocząć kolejny roku akademicki 1939/1940. Okupant - w obliczu zakończenia działań wojennych - nawoływał do podjęcia normalnej działalności. Rektor Lehr-Spławiński zawiadomił Niemców o decyzji Senatu i o otwarciu uniwersytetu. Dzień rozpoczęcia wykładów przesunięto z 11 listopada na 13, by nie stwarzać niebezpiecznych precedensów. Nabożeństwo inauguracyjne - zgodnie z planem - odbyło się w sobotę 4 listopada w kościele św. Anny, odprawił je ks. biskup Michał Godlewski. Po nabożeństwie profesorowie dowiedzieli o niespodziewanym wykładzie: „(...) w piątek wezwał do siebie rektora Obersturmbahnführer (...) Müller i poprosił go o urządzenie dla profesorów Uniwersytetu jego odczytu na temat stosunku Rzeszy Niemieckiej i narodowego socjalizmu do spraw nauki i uniwersytetów" 60 . Profesorowie po naradach zdecydowali o stawieniu się w poniedziałek 6 listopada w sali wykładowej. Oto, co wydarzyło się w gmachu uniwersyteckim. Müller w otoczeniu esesmanów chwilę przed godziną 12.00 wkroczył na uniwersytet, do-

\footnotetext{
${ }^{58}$ J. Baumgart, Aleksander Birkenmajer jako dyrektor Biblioteki Uniwersyteckiej w Poznaniu i Biblioteki Jagiellońskiej w Krakowie, „Roczniki Biblioteczne” 1969, z. 1-2, s. 173.

59 Tamże, s. 175.

${ }^{60}$ J. Gwiazdomorski, Wspomnienia z Sachsenhausen. Dzieje uwięzienia profesorów Uniwersytetu Jagiellońskiego 6 XI-9 II 1940, Kraków 1969, s. 18.
} 
syć bezceremonialnie przywitał się z rektorem, a do esesmanów powiedział: „Możemy zaczynać, po czym wszedł na salę, a za nim esesmani w czapkach, z karabinami. Oczywiście zrobiło to na zebranych niesamowite wrażenie i wywołało obawy co do przebiegu i zakończenia «odczytu» (...) Wasze usiłowania prowadzenia egzaminów i otwarcia Uniwersytetu są aktem złośliwym i wrogim wobec Rzeszy. Uważajcie się za aresztowanych. Zostaniecie przewiezieni do obozu jeńców, gdzie będziecie pouczeni o prawdziwej waszej sytuacji (...) Müller wyszedł, a esesmani zaczęli wyprowadzać zebranych. Traktowali wszystkich przez „ty”, potrącali ich kolbami, popychali, zrzucali ze schodów, kilku profesorów nawet pobili. Między innymi uderzono w twarz Stanisława Estreichera, Supniewskiego, rektora Zolla pchnięto kolbą w plecy" ${ }^{\prime \prime}$. W tym feralnym dniu na odczyt wybierali się również pracownicy biblioteki (wyżsi stopniem), ale na uniwersytet dotarł jedynie dr Aleksander Birkenmajer. „Ponieważ tego dnia zjawiło się w Bibliotece wyjątkowo dużo Niemców, którzy żądali załatwienia kwerend, ani dyrektor Edward Kuntze, ani dr Władysław Pociecha nie poszli na odczyt" ${ }^{\prime 2}$. Aleksander Birkenmajer został aresztowany wraz z 183 osobami w ramach hitlerowskiej akcji „Sonderaktion Krakau”. Przewieziono ich na Montelupich, potem do więzienia we Wrocławiu i do Sachsenhausen.

Była już noc, kiedyśmy pociągiem z Wrocławia dojechali do stacji końcowej. Wypędzono nas z wagonów, ustawiono w szeregi i pchnięto w drogę. Odległość obozu od stacji była dość znaczna, a droga błotnista. W ciemności przeszywanej co chwila oślepiającymi nas błyskami silnych latarek elektrycznych, obskoczeni wokół strażnikami, brnęliśmy - jak to tam było zwyczajne - biegiem, potykając się w wybojach drogi, popędzani wrzaskami eskorty. Starsi pośród nas, chorzy na serce, słabli wywracali się, co wywoływało chwilowe zamieszanie, zanim upadłego nie wykopnięto poza szereg i nie powleczono osobno ${ }^{63}$.

Osobę A. Birkenmajera parokrotnie przywołuje prof. Jan Gwiazdomorski:

Pierwsze zwolnienia z Sachsenhausen były 8 lutego 1940. Alle Krakauer antreten (Wszyscy krakowianie zbiórka). Nadszedł oficer i podoficer SS (...) kazali naprzód wystąpić Żydom. Nie było ich, bo przecież siedzieli w innym bloku. Potem kazano wystąpić wszystkim, którzy są urodzeni po roku 1900.

${ }^{61}$ Tamże, s. 22.

62 J. Baumgart, Aleksander Birkenmajer jako dyrektor Biblioteki Uniwersyteckiej w Poznaniu i Biblioteki Jagiellońskiej w Krakowie, dz. cyt., s. 176.

${ }^{63}$ S. Pigoń, Z przędziwa pamięci. Urywki wspomnień, dz. cyt., s. 186. 
Było ich 43 (...) Następnie zaczęto z kartoteki odczytywać nasze nazwiska, (...) którzy byli urodzeni przed rokiem 1900”64.

Profesor Birkenmajer został zwolniony jesienią 1940 roku. Można przypuszczać, że Niemcy zapamiętali polskość Kopernika ${ }^{65}$. O Sonderaktion Krakau tak pisali po latach profesorowie, Stanisław Pigoń:

Przed dwudziestu pięciu laty, dnia 6 listopada 1939 roku zaszedł w tych murach fakt, jakiemu podobnego nie notują dzieje ani naszego, ani żadnego innego z polskich uniwersytetów, jakiemu podobnego próżno by szukać w dziejach nauki polskiej. Fakt ludobójstwa uczonych ${ }^{66}$

\section{i Jan Gwiazdomorski:}

To zaś co wycierpieli na naszych oczach Ci, którzy w Sachsenhausen odeszli od nas na zawsze, przechodzi wszelką miarę i wszelkie wyobrażenie. Mam wrażenie, że pozbawienie ich życia przez rozstrzelanie musiałoby być uznane $\mathrm{w}$ ich cierpieniach za akt łaski ${ }^{67}$.

Profesor Aleksander Birkenmajer, zaraz po zwolnieniu z obozu w październiku 1940 roku, już w listopadzie zatrzymał się w Krakowie i zgłosił się do pracy w Bibliotece Jagiellońskiej, przemianowanej na „Staatsbibliothek Krakau". Starał się chronić zbiory przed wywózką i zniszczeniem. Jak wszyscy zatrudnieni Polacy udostępniał książki środowisku krakowskiemu, starał się przeszkodzić Niemcom w wywózkach książek, które zaczęly się już w sierpniu 1944 roku, za co został zwolniony. Można powiedzieć, iż miał szczęście, że tak to się skończyło. Po wojnie, w lutym 1945 roku, został oddelegowany przez Ministra Oświaty do zabezpieczenia zbiorów na terenie województw poznańskiego i pomorskiego ${ }^{68}$. Do Biblioteki Uniwersyteckiej w Poznaniu powrócił w marcu 1945 roku i objął kierownictwo po prze-

\footnotetext{
${ }^{64}$ J. Gwiazdomorski, Wspomnienia z Sachsenhausen. Dzieje uwięzienia profesorów Uniwersytetu Jagiellońskiego 6 XI-9 II 1940, dz. cyt., s. 245.

${ }^{65}$ Pierwsze zwolnienia więźniów nastąpiły w wyniku protestów międzynarodowej opinii publicznej i interwencji władz kilku państw neutralnych. Zob.: Wielka encyklopedia PWN, t. 25, Warszawa 2001, s. 370.

${ }^{66}$ S. Pigoń, Z przędziwa pamięci. Urywki wspomnień, dz. cyt., s. 227.

${ }^{67}$ J. Gwiazdomorski, Wspomnienia z Sachsenhausen. Dzieje uwięzienia profesorów Uniwersytetu Jagiellońskiego 6 XI-9 II 1940, dz. cyt., s. 8.

${ }^{68}$ J. Baumgart, Aleksander Birkenmajer jako dyrektor Biblioteki Uniwersyteckiej w Poznaniu i Biblioteki Jagiellońskiej w Krakowie, dz. cyt., s. 177.
} 
szło pięcioletniej przerwie. W jednym z okólników zgromadzonych w archiwum Biblioteki Uniwersyteckiej można znaleźć następujący fragment:

Gmach (...) zastałem poważnie uszkodzony i w $80 \%$ pozbawiony szyb; pustki w kasie Biblioteki, brak jakiejkolwiek namiastki budżetu, nieliczny zespół przedwojennych pracowników, zadania ogromne i nie cierpiące zwłoki - tym bardziej, że oprócz kierownictwa samej Biblioteki nałożono na mnie obowiązek zabezpieczenia i segregacji księgozbiorów «opuszczonych i porzuconych» na terenie dwu województw, w tym zaś względzie kompetencje moje niejasno określone, krzyżujące się z kompetencjami lub samowolą innych czynników ${ }^{69}$.

Dość szybko, bo już w październiku 1945 roku zorganizowano kształcenie i dokształcanie pracowników. Od 1946 roku we wszystkich działach odbywały się praktyki wewnętrzne $\mathrm{z}$ teorii i praktyki bibliotecznej. W tym samym roku przygotowywano się do złożenia egzaminu państwowego. Kurs trwał siedem miesięcy i obejmował wykłady z podstaw bibliotekoznawstwa; uczestniczyły $\mathrm{w}$ nim pięćdziesiąt cztery osoby $\mathrm{z}$ różnych poznańskich bibliotek. Przywrócenie Bibliotece Uniwersyteckiej stanu sprzed wojny było zasługą wszystkich zatrudnionych $\mathrm{w}$ bibliotece, na czele $\mathrm{z}$ dyrektorem. A. Birkenmajer angażował się społecznie, był przewodniczącym Oddziału Poznańskiego (ZBiA), działał w Poznańskim Towarzystwie Przyjaciół Nauki (PTPN), został wybrany na członka czynnego Polskiej Akademii Umiejętności, a dokonania naukowe profesora zyskały najwyższe uznanie. W lipcu 1947 roku wrócił do Krakowa, przejął kierownictwo Biblioteki Jagiellońskiej (dyrektor Edward Kuntze był już schorowany i musiał przejść na emeryturę). Wrócił do swojej biblioteki, by zacząć nowy rozdział pracy bibliotekarskiej, pedagogicznej, naukowej i społecznej.

Był doskonałym gospodarzem: „Pracę umiał zorganizować i sobie i innym, potrafił zawsze dostrzec sprawy najważniejsze. Był dyrektorem dwóch bibliotek uniwersyteckich, które należały za jego kierownictwa do najlepiej zorganizowanych. Tę działalność przerwała niespodziewanie, w 1951 r., wiadomość o nominacji na profesora zwyczajnego bibliotekoznawstwa Uniwersytetu Warszawskiego"70.

${ }^{69}$ ABP, Okólnik nr 8 pro 1945, s. 2.

${ }^{70}$ J. Baumgart, Aleksander Birkenmajer jako dyrektor Biblioteki Uniwersyteckiej w Poznaniu i Biblioteki Jagiellońskiej w Krakowie, dz. cyt., s. 191. 
II. 11. Obwieszczenie w sprawie pomocy organizacji CARE dla Pracowników BU, czerwiec 1946.
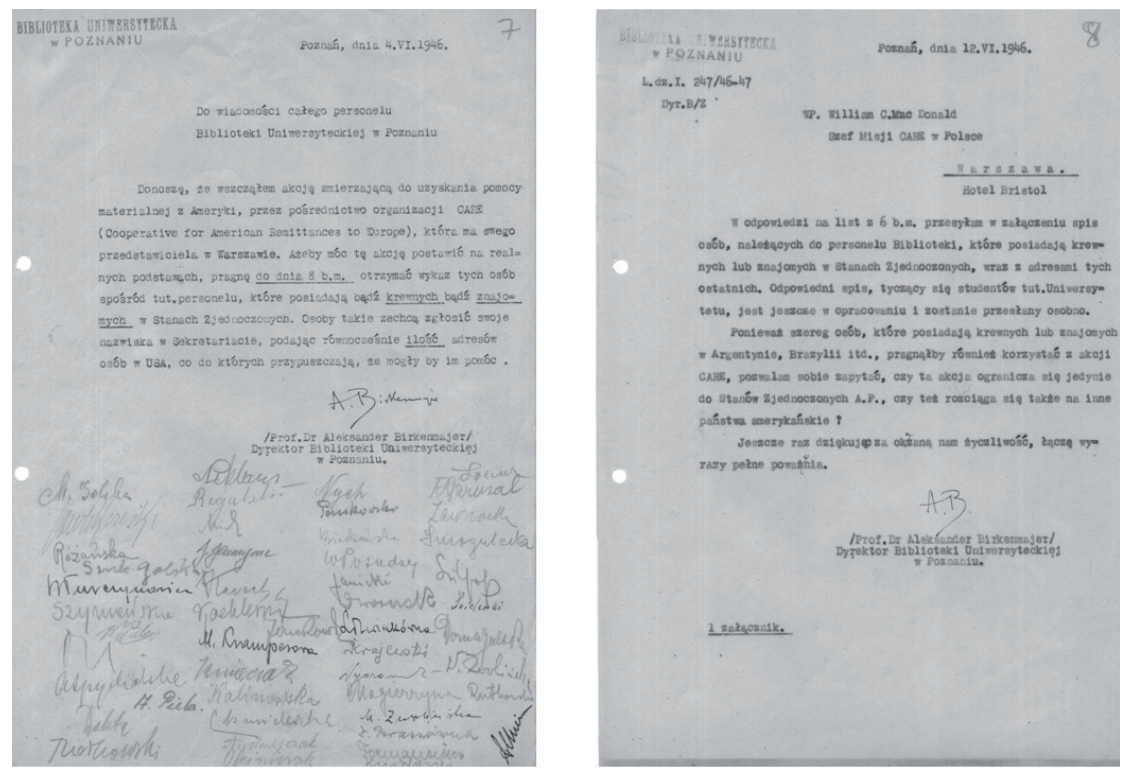

Źródło: Archiwum Biblioteki Uniwersyteckiej w Poznaniu, sygn. 12.

\section{Na marginesie}

W czerwcu 1946 roku na biurku wśród codziennej korespondencji dyrektor A. Birkenmajer znalazł list nadany przez Towarzystwo C.A.R.E (Cooperative for American Remittances to Europe $\left.{ }^{71}\right)$, utworzone po zakończeniu II wojny, które organizowało pomoc dla potrzebujących. W związku z tym Birkenmajer wydał rozporządzenie, aby wszyscy pracownicy biblioteki zgłosili adresy krewnych i znajomych w Stanach, którzy mogliby włączyć się w organizowanie humanitarnej pomocy za pośrednictwem C.A.R.E.

Sporządzono kwestionariusze, w których - obok danych osobowych - znajdowały się także zapytania o potrzeby i specjalne życzenia; ankietę kończyło pytanie dotyczące losów wojennych. Pomoc objęła wszystkich. Dyrektor swoją troską otoczył pracowników i ich rodziny, nie zapomniał też o studentach: im także złożono propozycję skorzystania $\mathrm{z}$ tej formy pomocy. Kwestionariusze są cennym dokumentem socjologicznym, powstałym po II wojnie światowej, a jednocześnie pewnego rodzaju listą marzeń.

${ }^{71}$ Stowarzyszenie Amerykańskiej Pomocy Powszechnej (Cooperative For American Relief Everywhere, CARE) [w:] Britannica. Edycja polska, t. 41, Poznań 1997, s. 45. 


\section{Il. 12. Kwestionariusze rodziny p. Józefa Regulskiego, pracownika BU, dla CARE, wrzesień 1946.}
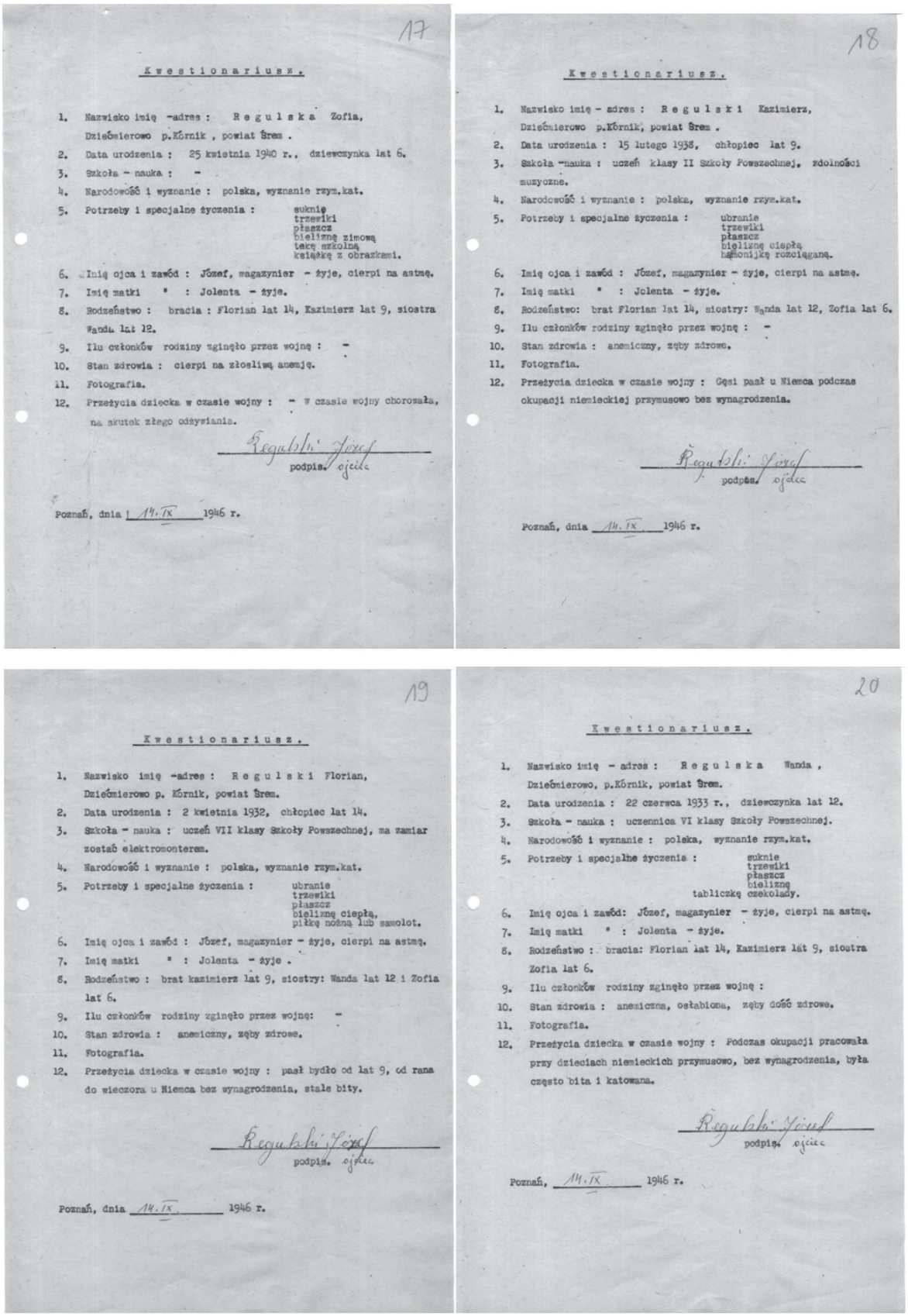

Źródło: Archiwum Biblioteki Uniwersyteckiej w Poznaniu, sygn. 12. 


\section{Zamiast pożegnania}

We wspomnieniach jednego z uczniów czytamy: „W miarę, jak życie oddala nas od Profesora, rośnie jego wielkość i bliskość (...). Był indywidualnością wybitną. Jako człowiek i uczony łączył w sobie rzadkie cechy szlachetności, skromności i prawości. Był przykładem niepospolitej pracowitości i wiedzy. W swej ostatniej drodze wrócił do swojego umiłowanego Krakowa. Jego przyjaciele, koledzy, wychowankowie, studenci i studentki nie ukrywali łez, zgromadzeni w jesienny, październikowy dzień na cmentarzu Rakowickim"72.

\section{Podsumowanie}

Poznańczycy, krakowianie, lwowianie - twórcy nowoczesnego bibliotekarstwa, teoretycy i praktycy, uczeni, nauczyciele, mistrzowie... Łączył ich ten sam zachwyt nad książką - książką w służbie profesorom i studentom, książką $\mathrm{w}$ aspekcie historii bibliotekarstwa, książką w aspekcie bibliografii teoretycznej i praktycznej.

Edward Kuntze, Stefan Vrtel-Wierczyński i Aleksander Birkenmajer należeli do elity, grona ludzi odpowiedzialnych, służących innym mądrością, wiedzą i troską. Nietuzinkowi społecznicy, usuwający siebie w cień, by wyróżnić innych. Patrioci. Jedni z wielu bibliotekarzy II Rzeczypospolitej i Polski powojennej.

\section{Abstract \\ The famous citizens from Poznań: Edward Kuntze, Aleksander Birkenmajer, Stefan Vrtel-Wierczyński and their reformative politics in librarianship as a source of inspiration for librarians}

The author presents, in five points, the scientific and professional profiles of librarians, directors of Poznań University Library, related not only to Poznań environment: E. Kuntze, A. Birkenmajer, S. Vrtel-Wierczyński. In the article it is shown their role in the creation of modern librarianship in Poland in XX century.

${ }^{72}$ J. Kapuścik, Profesor ze wspomnień ucznia, dz. cyt., s. 179. 